\title{
KEJADIAN ANEMIA PADA IBU HAMIL DI PUSKESMAS KEDUNGMUNDU KOTA SEMARANG
}

\author{
Witri Hastuti, Yulen Birahy \\ STIKes Karya Husada Semarang \\ Jl. Kompol R. Soekanto 46, Sambiroto, Semarang, Jawa Tengah \\ Email : wi3.yahoed@gmail.com
}

\begin{abstract}
ABSTRAK
Latar Belakang: Anemia merupakan indikator untuk gizi dan kesehatan yang buruk. Anemia pada ibu hamil sangat terkait dengan mortalitas dan morbiditas pada ibu dan bayi. Hasil studi pendahuluan yang dilakukan peneliti di Puskesmas Kedungmundu Kota Semarang jumlah ibu hamil yang mengalami anemi Tahun 2018 ibu hamil dengan anemia dari bulan Januari sampai April sebanyak 29,5\% ibu. Tujuan penelitian ini adalah mengetahui kejadian dan faktor-faktor yang berhubungan dengan anemia pada ibu hamil di Puskesmas Kedungmundu. Metode Penelitian: Penelitian ini menggunakan jenis penelitian analitik korelatif dengan desain pendekatan cross sectional. Sampel dalam penelitian di Puskesmas Kedungmundu berjumlah 73 responden. Teknik sampling yang digunakan yaitu proportional stratified random sampling. Hasil Penelitian: Sejumlah 73 ibu hamil didapatkan sebanyak 47 (64,4,0\%) responden mengalami anemia saat hamil, sedangkan 26 responden $(35,6 \%)$ tidak mengalami anemia. Faktor yang berhubungan dengan kejadian anemia pada ibu hamil antara lain umur ( $p$ value : 0,000$)$, paritas ( $p$ value : 0,000$)$ dan pengetahuan ibu ( $p$ value : 0,005 ). Kesimpulan: Sebagian besar ibu hamil di Puskesmas Kedungmundu Kota Semarang mengalami anemia sehingga diharapkan ibu hamil mau mengikuti kelas ibu hamil dan sosialisasi tentang kehamilan dan paling penting mengkonsumsi makanan yang bergizi.
\end{abstract}

Kata Kunci :anemia; hemoglobin; ibu hamil

\begin{abstract}
Background: Anemia is an indicator of nutrition and poor health. Anemia in pregnant women is strongly associated with mortality and morbidity in mothers and infants. The results of a preliminary study conducted by researchers at the Kedungmundu Community Health Center, Semarang City, number of pregnant women who experience anemia in 2018 pregnant women with anemia from January to April were $29.5 \%$ of mothers. The purpose of this study was to determine the incidence and factors associated with anemia in pregnant women at the Kedungmundu Health Center. Method: This study used a type of correlative analytic research with a cross sectional design. The sample in the study at Kedungmundu Health Center 73 respondents. The sampling technique used is proportional stratified random sampling. Result: A total of 73 pregnant women found that $47(64.4 .0 \%)$ respondents had anemia during pregnancy, while 26 respondents $(35.6 \%)$ did not experience anemia. Factors related to the incidence of anemia in pregnant women include age ( $p$ value: 0,000 ), parity ( $p$ value: 0,000$)$ and mother's knowledge ( $p$ value: 0,005 ). Conclusion: Most pregnant women at the Kedungmundu Health Center in Semarang City are anemia so expect pregnant women to take classes in pregnant women and socialization about pregnancy and most importantly consume nutritious foods.
\end{abstract}

Keywords: anemia, hemoglobin, pregnant women. 


\section{LATAR BELAKANG}

Anemia merupakan suatu kondisi dimana jumlah dan ukuran sel darah merah atau konsentrasi hemoglobin dibawah nilai batas normal akibatnya dapat mengganggu kapasitas darah untuk mengangkut oksigen ke sekitar tubuh.Anemia merupakan indikator untuk gizi buruk dan kesehatan yang buruk.Anemia pada ibu hamil sangat terkait dengan mortalitas dan morbiditas pada ibu dan bayi, termasuk resiko keguguran, lahir mati, prematuritas dan berat bayi lahir rendah (WHO 2013).

Anemia pada kehamilan merupakan salah satu masalah nasional karena mencerminkan nilai kesejahteraan sosial ekonomi masyarakat dan pengaruhnya sangat besar terhadap kualitas sumber daya manusia. Anemia pada ibu hamil disebut "potensial danger to mother and child"(potensial membahayakan ibu dan anak). Oleh karena itu anemia memerlukan perhatian serius dari semua pihak yang terkait dalam pelayanan kesehatan (Proverawati dkk, 2011).

Berdasarkan hasil Riset Kesehatan Dasar (Riskesdas) tahun 2013 prevalensi anemia pada ibu hamil secara nasional mencapai $37,1 \%$. Pemberian tablet $\mathrm{Fe}$ di Indonesia pada tahun 2015 sebesar $85 \%$. Presentase ini mengalami peningkatan dibandingkan padaa tahun 2014 yang sebesar 83,3\% karena ketidak patuhan ibu mengkonsumsi tablet $\mathrm{Fe}$ selama masa kehamilan. Anemia dalam kehamilan dapat disebabkan karena ketidakpatuhan ibu hamil mengkonsumsi tablet $\mathrm{Fe}$ dan kurangnya pengetahuan tentang pentingnya tablet zat besi untuk kehamilannya Selain itu jumlah paritas, status gizi ibu hamil dan frekuensi ANC ternyata juga mempengaruhi kejadian anemia pada ibu hamil (Amalia dkk, 2017).

Angka kematian ibu (AKI) di Provinsi Jawa Tengah pada Tahun 2016 sebesar 109,65 per 100.000 kelahiran hidup 602 kasus Faktor-faktor penyebab kematian ibu yakni pendarahan $(21,26 \%)$, hipertensi $(27,08 \%)$, infeksi $(4,82 \%)$, gangguan sistem peredaran darah $(13,29 \%)$, dan lain-lain (33,22\%) (Kemenkes, 2017). Menurut profil Dinas Kesehatan Kota Semarang pada tahun 2016 jumlah ibu hamil yang anemia sebanyak $19,58 \%$. Anemia pada ibu hamil ini masih cukup tinggi dan penting untuk cepat ditangani mengingat dampaknya yang dapat menyebabkan kematian baik pada ibu maupun janin yang dikandungnya (Dinkes, 2017).

Faktor-faktor Yang Berhubungan Dengan Anemia Dalam Kehamilan Umur Salah satu faktor yang di duga berhubungan dengan kejadian anemia pada ibu hamil adalah usia ibu saat hamil. Usia yang dianggap beresikotinggi untukhamil pada ibu hamil berusia dibawah 20 tahun dan diatas 35 tahun. Sedangkan yang tidak beresiko tinggi bila ibu hamil berusia antara 20-35 tahun .(Purba $R$, 2011. Kehamilan $<20$ tahun merupakan kehamilan beresiko tinggi 2-4 kali lebih tinggi dibandingkan dengan kehamilan pada wanita dengan umur reproduksi sehat. Hal ini terjadi karena sistem reproduksi mereka belum matur dan mereka belum memiliki transfer plasenta seperti wanita dewasa. Selain kehamilan di bawah usia 20 tahun, kehamilan dengan usia diatas 35 tahun juga merupakan kehamilan beresiko tinggi. Wanita yang hamil dalam usia yang terlalu tua yaitu $>35$ tahun pun akan rentan terhadap anemia. Hal ini terkait dengan penurunan daya tahan tubuh sehingga mudah terkena berbagai infeksi selama kehamilan.(Varney, 2012)

Hasil studi pendahuluan yang dilakukan peneliti di Puskesmas Kedungmundu Kota Semarang jumlah ibu hamil yang mengalami anemia pada tahun 2016 pada bulan September sampai dengan Desember sebanyak $28,1 \%$ dan pada tahun 2017 mengalami peningkatan sebanyak 28,9\%. Tahun 2018 ibu hamil dengan anemia dari bulan Januari sampai April sebanyak $29,5 \%$ ibu.

Berdasarkan fenomena yang ada karena tingginya prevalensi anemia pada ibu hamil diwilayah kerja Puskesmas maka peneliti tertarik untuk melakukan penelitian tentang "Kejadian Anemia serta Faktor-Faktor Yang Berhubungan Pada Ibu Hamil Di Puskesmas Kedungmundu Kota Semarang".

\section{METODE}

Penelitian ini menggunakan jenis penelitian analitik korelatif dengan desain pendekatan cross sectional yaitu pengambilan data yang dilakukan dalam satu kurun waktu.Peneliti mengumpulkan 
data dari sampel pada waktu yang bersamaan.Penelitian ini menggunakan desain cross sectional karena prevalensi masalah yang terjadi cukup besar.Selain itu studi cross sectional dapat menganalisis adanya hubungan beberapa variabel (dependen dan independen) dan lebih praktis untuk dilaksanakan.(Notoatmodjo, 2014)

Sampel dalam penelitian ini diambil dari sebagian populasi yaitu sebanyak 73 sampel ibu hamil dengan kehamilan trimester I dan trimester II, teknik sampling yang digunakan untuk mengambil sampel yaitu proportional stratified random sampling).

\section{HASIL}

\section{Analisis Univariate}

Mayoritas usia ibu pada penelitian ini berumur kurang dari 20 tahun $(71,2 \%)$, seperti terdapat pada table 1

Tabel 1 Distribusi Frekuensi Responden Menurut Umur Pada Ibu Hamil Di Puskesmas Kedungmundu Kota Semarang Tahun 2018

\begin{tabular}{ccc}
\hline Umur ibu & Jumlah & Presentase (\%) \\
\hline $\begin{array}{c}\text { Resiko tinggi (< } \\
20 \text { dan }>35 \\
\text { thn) }\end{array}$ & 52 & 71,2 \\
$\begin{array}{c}\text { Resiko rendah } \\
(20-35 \text { thn) }\end{array}$ & 21 & 28,8 \\
\hline Total & 73 & 100,0 \\
\hline
\end{tabular}

Tabel 2 Distribusi Frekuensi Responden Menurut Paritas Pada Ibu Hamil Di Puskesmas Kedungmundu Kota Semarang Tahun 2018

\begin{tabular}{|c|c|c|c|c|c|}
\hline \multirow{3}{*}{ Umur ibu } & \multicolumn{4}{|c|}{ Status anemia } & \multirow{3}{*}{$P$ value } \\
\hline & \multicolumn{2}{|c|}{ Anemia } & \multicolumn{2}{|c|}{ Tidak anemia } & \\
\hline & $\mathrm{n}$ & $\%$ & $\mathrm{n}$ & $\%$ & \\
\hline $\begin{array}{c}\text { Resiko } \\
\text { tinggi }\end{array}$ & 45 & 86,5 & 7 & 13,5 & 0,000 \\
\hline $\begin{array}{l}\text { Resiko } \\
\text { rendah }\end{array}$ & 2 & 9,5 & 19 & 90,5 & \\
\hline Jumlah & 47 & 64,4 & 26 & 35,6 & \\
\hline
\end{tabular}

Berdasarkan tabel 2 diatas dapat diketahui bahwa jumlah ibu hamil yang memiliki riwayat pernah melahirkan $>4$ kali adalah sebesar $33(45,2 \%)$ sedangkan jumlah ibu hamil yang memiliki riwayat pernah melahirkan $>4$ kali adalah sebesar $40(54,8 \%)$.

Tabel 3 Distribusi Frekuensi Responden Menurut Tingkat Pengetahuan Pada Ibu Hamil Di Puskesmas Kedunhmundu Kota Semarang Tahun 2018

\begin{tabular}{ccc}
\hline $\begin{array}{c}\text { Pengetahuan } \\
\text { ibu }\end{array}$ & Jumlah & Presentase (\%) \\
\hline Kurang & 8 & 11,0 \\
Cukup & 10 & 13,7 \\
Baik & 55 & 75,3 \\
\hline Total & 73 & 100,0 \\
\hline
\end{tabular}

Berdasarkan tabel .3 diatas dapat diketahui bahwa tingkat pengetahuan ibu hamil tentang anemia dan tablet Fe kategori baik sebanyak 55 responden $(75,3 \%)$ pengetahuan cukup sebanyak 10 responden $(13,7 \%)$, pengetahuan kurang baik sebanyak 8 responden $(11,0 \%)$.

Tabel 4 Distribusi Frekuensi Responden Menurut Status Anemia Pada Ibu Hamil Di Puskesmas Kedungmundu Kota Semarang Tahun 2018

\begin{tabular}{ccc}
\hline $\begin{array}{c}\text { Status } \\
\text { anemia }\end{array}$ & Jumlah & Presentase (\%) \\
\hline Anemia & 47 & 64,4 \\
$\begin{array}{c}\text { Tidak } \\
\text { anemia }\end{array}$ & 26 & 35,6 \\
\hline Total & 73 & 100,0 \\
\hline
\end{tabular}

Berdasarkan tabel 4 dapat diketahui bahwa Dari 73 ibu hamil sebanyak $47 \quad(64,4,0 \%)$ responden mengalami anemia saat hamil, sedangkan 26 responden $(35,6 \%)$ tidak mengalami anemia.

\section{Analisis Bivariate}

Tabel 5 Hubungan antara umur ibu dengan anemia pada ibu hamil di Puskesmas Kedungmundu Kota Semarang

\begin{tabular}{lcc} 
& $2018(\mathrm{n}=47)$ & \\
\hline \multicolumn{1}{c}{ Paritas } & Jumlah & Presentase $(\%)$ \\
\hline $\begin{array}{l}\text { Resiko tinggi } \\
\begin{array}{l}4 \\
\text { Resiko rendah } \\
<4\end{array}\end{array}$ & 33 & 45,2 \\
\hline Total & 40 & 54,8 \\
\hline
\end{tabular}


Hasil penelitian menunjukan bahwa dari 52 responden yang umurnya beresiko tinggi sebagian besar mengalami anemia yaitu sebanyak $45(86,5 \%)$ sementara yang tidak anemia sebanyak 7 (13,5\%). Dan dari 21 responden yang beresiko rendah sebagian besar tidak mengalami anemia sebagian besar tidak mengalami anemia yaitu sebanyak 19 (90,5\%) sementara yang mengalami anemia sebanyak 2 $(9,5 \%)$.nilai probalitasp-value 0,000 karena kurang dari 0.05 maka Ho ditolak dan Ha diterima sehingga dapat diartikan ada hubungan antara umur ibu dengan anemia pada ibu hamil.

Tabel 6 Hubungan antara paritas ibu dengan anemia pada ibu hamil di Puskesmas Kedungmundu Kota SemarangTahun $2018(n=47)$

\begin{tabular}{|c|c|c|c|c|c|}
\hline \multirow{3}{*}{ Paritas ibu } & \multicolumn{4}{|c|}{ Status anemia } & \multirow{3}{*}{$\begin{array}{c}P \\
\text { value }\end{array}$} \\
\hline & \multicolumn{2}{|c|}{ Anemia } & \multicolumn{2}{|c|}{ Tidak anemia } & \\
\hline & $\mathrm{n}$ & $\%$ & $\mathrm{~N}$ & $\%$ & \\
\hline Resiko & 33 & 100 & 0 & 0 & 0,000 \\
\hline $\begin{array}{l}\text { Resiko } \\
\text { rendah }<4\end{array}$ & 14 & 35 & 26 & 65 & \\
\hline Jumlah & 47 & 64,4 & 26 & 35,6 & \\
\hline
\end{tabular}

Hasil penelitian menunjukan bahwa dari 33 responden yang paritas lebih dari 4 beresiko tinggi sebagian besar mengalami anemia yaitu sebanyak $33(100 \%)$ sementara yang tidak anemia sebanyak $0(0 \%)$. Dan dari 40 responden yang paritas kurang dari 4 sebagian besar tidak mengalami anemia yaitu sebanyak $26(65,0 \%)$ sementara yang mengalami anemia sebanyak 14 $(35,0 \%)$.Nilai probalitas $P$-value 0,000 karena kurang dari 0.05 maka Ho ditolak dan Ha diterima sehingga dapat diartikan ada hubungan antara paritas ibu dengan anemia pada ibu hamil.

Tabel 7 Hubungan antara tingkat pengetahuan ibu dengan anemia pada ibu hamil di Puskesmas Kedungmundu Kota Semarang Tahun $2018(n=47)$

\begin{tabular}{|c|c|c|c|}
\hline \multirow{3}{*}{ Pengetahuan ibu } & \multicolumn{2}{|c|}{ Status anemia } & \multirow{3}{*}{$\begin{array}{c}P \\
\text { value }\end{array}$} \\
\hline & Anemia & $\begin{array}{c}\text { Tidak } \\
\text { anemia }\end{array}$ & \\
\hline & $\%$ & $\%$ & \\
\hline
\end{tabular}

\begin{tabular}{cccccc}
\hline Kurang dan cukup & 17 & 94,4 & 1 & 5,6 & 0,005 \\
Baik & 30 & 54,5 & 25 & 45,5 & \\
\hline Jumlah & 47 & 64,4 & 26 & 35,6 & \\
\hline
\end{tabular}

Hasil penelitian menunjukan bahwa dari 18 responden yang pengetahuannya kurang dan cukup sebagian besar mengalami anemia yaitu sebanyak $17(94,4 \%)$ sementara yang tidak anemia sebanyak 1 (5,6\%). Dan dari 55 responden pengetahuan sebagian besar mengalami anemia yaitu sebanyak 30 (54,5\%) sementara yang mengalami anemia sebanyak 25 $(45,5 \%)$.nilai probalitas $p$-value0,005 karena kurang dari 0.05 maka $\mathrm{Ho}$ ditolak dan $\mathrm{Ha}$ diterima sehingga dapat diartikan ada hubungan antara pengetahuan ibu dengan anemia pada ibu hamil.

\section{PEMBAHASAN}

Tabel 1 hasil penelitian menunjukan bahwa umur ibu hamil menurut peneliti responden yang beresiko <20->35 sebagian besar yaitu 52 $(71,2 \%)$. Hasil penelitian ini didukung dengan penelitian (Handayani, 2014) Ini menunjukkan bahwa kelompok ibu hamil yang berumur dibawah 20 tahun dan lebih dari 35 tahun memiliki kemungkinan untuk mengalami anemia kali atau lebih besar dibandingkan kelompok ibu hamil dengan umur antara 20-35 tahun. Hal itu dikarenakan pada umur $<20$ tahun masih terjadi pertumbuhan yang membutuhakn zat gizi lebih banyak dibandingkan dengan umur di atasnya. Bila zat gizi yang dibutuhkan tidak terpenuhi, akan terjadi kompetisi zat gizi antara ibu dengan bayinya. Sedangkan ibu hamil di atas 35 tahun lebih cenderung mengalami anemia disebabkan cadangan zat besi yang mulai menurun.(Varney, 2012)

Tabel 2 menunjukan bahwa paritas ibu hamil menurut peneliti responden yang beresiko lebih dari 4 kali sebanyak yaitu $40(54,8 \%)$. Menurut Arisman (2010) menyatakan bahwa jumlah paritas lebih dari 4 merupakan faktor terjadinya anemia disebabkan karena terlalu sering hamil dapat menguras cadangan zat besi tubuh ibu. Jumlah anak yang dilahirkan wanita lama 
hidupnya sangat mempengaruhi kesehatannya.(Aryanti dkk, 2014)

Tabel 3 hasil penelitian menunjukan bahwa tingkat pengetahuan ibu hamil menurut peneliti responden yang pengetahuan baik sebanyak 55 $(75,3 \%)$. Hasil penelitian ini didukung oleh (aisyah, 2014) menunjukkan bahwa semakin baik pengetahuan ibu hamil tentang anemia dan tablet Fe semakin kecil kemungkinan mengalami anemia dalam kehamilannya (Sulistyowati, 2012).

Pada tabel 4 hasil penelitian yang dilakukan Dari 73 ibu hamil sebanyak 47 (64,4,0\%) responden mengalami anemia saat hamil, sedangkan 26 responden $(35,6 \%)$ tidak mengalami anemia.

Berdasarkan tabel 5tabulasi silang hubungan umur dengan kejadian anemia pada ibu hamil di Puskesmas Kedugmundu Kota Semarang, diketahui bahwa hubungan umur dengan kejadian anemia pada ibu hamil sebanyak 52 responden, 7 responden $(13,5 \%)$ dan 45 responden $(86,5 \%)$ mengalami anemia karena pada umur $<20$ tahun perkembangan biologis dalam hal ini alat reproduksi belum optimal. sedangkan untuk umur $>35$ tahun rentan terhadap anemia terkait dengan penurunan daya tahan tubuh sehingga tubuh mudah terkena infeksi karena ibu yang terkena penyakit kronik infeksi seperti TBC, cacing usus dan malaria juga penyebab terjadinya anemia karena menyebabkan terjadinya peningkatan penghancuran sel darah merah dan terganggunya eritrosit .(Aryanti dkk, 2013). Responden yang tidak beresiko terjadi anemia sebanyak 21 responden, 19 responden (90,5\%) diantaranya tidak mengalami anemia karena diantaranya memiliki umur yang sudah matang dalam alat reproduksi dan 2 responden $(9,5 \%)$ lainya mengalami anemia karena umur yang di atas 35 tahun pun resiko mengalami perdarahan. Berdasarkan hasil penelitian tersebut ada hubungan umur dengan anemia pada ibu hamil di Puskesmas Kedungmundu Kota Semarang Tahun 2018 ( $p$ value: 0.000).

Berdasarkan tabel 6 tabulasi silang hubungan paritas kejadian anemia pada ibu hamil di Puskesmas Kedugmundu Kota Semarang, diketahui bahwa hubungan paritas dengan kejadian anemia pada ibu hamil sebanyak 33 responden, 0 responden $(0,0 \%)$ tidak mengalami anemia dan 33 responden (100\%) mengalami anemia karena pada paritas $>4$ kali beresiko terjadi. Hal ini disebabkan karena pada kehamilan yang berulang menimbulkan kerusakan pada pembuluh darah dan dinding uterus yang biasanya mempengaruhi sirkulasi nutrisi ke janin dan semakin sering seorang wanita melahirkan maka semakin besar resiko kehilangan darah.(Ariyani A, 2016). Responden yang tidak beresiko terjadi anemia sebanyak 40 responden, 26 responden $(65,0 \%))$ diantaranya tidak mengalami anemia karena diataranya memiliki jumlah kelahiran dibawah $<4$ kali dan 14 responden $(35,0 \%)$ lainya mengalami anemia karena jumlah kelahiran diatas 4 kali melahirkan. Berdarkan hasil penelitian tersebut ada hubungan paritas dengan anemia pada ibu hamil di Puskesmas Kedungmundu Kota Semarang Tahun 2018 ( $p$ value: 0.000).

Berdasarkan tabel 7 tabulasi silang hubungan tingkat pengetahuan dengan kejadian anemia pada ibu hamil di Puskesmas Kedugmundu Kota Semarang, diketahui bahwa hubungan tingkat pengetahuan dengan kejadian anemia pada ibu hamil sebanyak 18 responden yang pengetahuan kurang dan cukup, 1 responden (5,6\%) tidak mengalami anemia dan 17 responden $(94,4 \%)$ mengalami anemia karena pada tingkat pengetahuan ibu hamil berpengaruh terhadap pola konsumsi makanan terutama zat besi. (Budiami, 2011).Responden yang beresiko terjadi anemia sebanyak 55 responden yang tingkat pengetahuannya baik, 25 responden $(45,5 \%)$ diantaranya tidak mengalami anemia karena diataranya memiliki pengetahuan yang baik dan 30 responden $(54,5 \%)$ lainya mengalami anemia karena mempunyai tingkat pengetahuan yang baik tetapi tidak mengaplikasikan pengetahuan yang diperoleh dalam kehidupan sehari-hari yaiti mengkonsumsi makanan hijau dan protein yang cukup. Berdarkan hasil penelitian tersebut ada hubungan tingkat pengetahuan dengan anemia pada ibu hamil di Puskesmas Kedungmundu Kota Semarang Tahun 2018 ( $p$ value: 0.005). 


\section{KESIMPULAN DAN SARAN}

Hasil penelitian dapat disimpulkan bahwa sebagian besar ibu hamil mengalami anemia. Faktor yang berhubungan dengan kejadian anemia adalah umur, paritas dan pengetahuan. Diharapkan ibu hamil mau mengikuti kelas ibu hamil dan sosialisasi tentang kehamilan dan paling penting mengkonsumsi makanan yang bergizi dan untuk Dinas Kesehatan semarang diharapkan untuk melakukan penigkatan upaya pencegahan anemia pada ibu hamil melalui penyuluhan tentang anemia setiap 1 bulan sekali dan lebih tingkatkan kelas ibu hamil.

\section{REFERENSI}

Proverawati, Atikah. 2011. Anemia dan anemia kehamilan.Yogyakarta : Nuha Medika

Aisyrah, S. 2012. Faktor-Faktor yang Berhubungan dengan Kejadian Anemia pada Ibu Hamil Di Wilayah Kerja Puskesmas Bajeng Kecamatan Bajeng Kabupaten gowa tahun 2014.Jakarta. FKM UI.

Amalia S, Afriyani R, Utami S .2017. Faktor resiko kejadian anemia pada ibu hamil di Rumah Sakit BARI Pelembang

Kemenkes. 2016. Profil Kesehatan Indonesia 2016. Jakarta : Kemenkes RI 2012
Dinkes. 2017. Profil Kesehatan Provinsi Jawa Tengah 2016, semarang : dinas kesehatan kota semarang 2016

Sulistiyanti A . 2015. Hubungan tingkat pengetahuan ibu hamil tentang anemia dengan kepatuhan konsumsi tablet Fe di Wilayah Kerja Puskesmas Masaran I Sragen.

Budiami W, Subagio H W .2011. Hubungan pengetahuan, sikap dan motivasi dengan kepatuhan mengkonsumsi tablet besi folat pada ibu hamil.http://ejurnal.undip.ac.id/3898/.UNDIP.

Ariyani A, 2016. Faktor-Faktor Yang Mempengaruhi Kejadian Anemia Pada Ibu Hamil Trimester III di Wilayah Kerja Puskesmas Mojolaban Kabupaten Su-koharjo. Naskah Publikasi IImu Gizi Fakultas IImu Kesehatan UMS.

Aryanti Wardiah, Sumini Setiawati, Riyani, Riska Wandiri, Lidya Aryanti. 2013. Faktor-faktor yang mempengaruhi kejadian anemia pada ibu hamil di wilayah kerja Puskesmas Sekampung Kabupaten Lampung Timur tahun 2013. PSIK Universitas Malahayati Bandar Lampung.

Varney. 2012. Buku Ajar Asuhan Kebidanan .Volume 1. Edisi4. Jakarta : EGC.

Fr. Sulistyowati. 2012. Hal 5. Gambaran Tingkat Pengetahuan Ibu Hamil perawatan bayi.Diglosia Media Yogyakarta.

Notoatmodjo, Soekidjo. 2014. Metodelogi Penelitian Kesehatan. Jakarta: Rineka Cipta 